\title{
STUDIES ON PESTS IN 4 COCONUT CULTIVARS \\ IN LAMPUNG PROVINCE
}

\author{
By \\ Wily A. Baringbing and Bariyah-Baringbing ${ }^{1}$
}

\begin{abstract}
A three-year field study to investigate species of pests on four (4) coconut cultivars: PB-1 21, PB-111, KH17VA-1 and dwarf Salak, was carried out in Lampung province involving 11 visits from November 1991 to April 1993. Only two regencies: Lampung Utara and Lampung Tengah with 3 and 1 sub-districts, respectively were surveyed But only three sub-districts of Lampung Utara: Sungkai Selatan, Manggala and Mesuji and only Terbanggi Besar in Lampung Tengah were studied

Observations of Brontispa longissima Gestro, Plesispa reichei Chapuis, Oryctes rhinoceros Linnaeus, Xylotropus Gideon (Linnaeus), Rhynchophorus vulneratus (Panzer), and the others were studied.

Results of the study showed that no cultivars were resistant to any species of pests in Lampung province. There were 19 species of pests, 2 of which do not belong to the insect present in the 2 regencies. The 17 species of insects belong to 4 orders including: Coleoptera, Lepidoptera, Homoptera and Orthoptera in 3, 5, 1 and 1 families, respectively.
\end{abstract}

\section{INTRODUCTION}

Lampung province is one of the potential areas for developing some industrial crops including coconut for the land is broad with low-land area, and the population is relatively low (Baringbing, 1992c). Statistics show that the province ranks 7 in the number of coconut palms planted at 177,691 hectares. From the 1989 data, we could see the increased land utilization at the rate of $9.68 \%$ per annum. (Anonymous, 1989; 1990). Even with this, coconut area in Lampung only constitute $5.33 \%$ of the total coconut area in Indonesia with an average production of 111,890 tons of copra or $5.01 \%$ of national production.

Coconut palms planted by smallholders consisted of Tall varieties. During the last several years, farmers started cultivating coconut hybrid and PB-121, PB-111 AND KHINA-1 were among those preferred by big landholders. Intercropping is being practiced particularly by smallholders where they plant several seasonal vegetation as cash crops to increase their Income. Beside seasonal vegetation, other commodities such as cacao, coffee and many other fruits were also found in small garden (Baringbing, 1991). In contrast to the small farmers, big landholders only grew cacao among coconut palms particularly in the regencies of Lampung Utara and Lampung Tengah.

Meanwhile, one of the several factors responsible for decreasing coconut production Mi both small and big farmers, is the presence of pests and diseases.

The objective of this study was to determine the various pests that attacked coconut palms in Lampung province.

\footnotetext{
${ }^{1}$ Coconut Research Sub-institute, Pakuwon, West Java and Research Institute for Species \& Medicinal Crops, Bogor, respectively.
} 


\section{MATERIALS AND METHODS}

A three-year field experiment, beginning from November 1991 until May 1993, to study the various pests which attacked 3 coconut hybrid cultivars including PB-121, PB-111, KHINA-1 and dwarf Salak were conducted in Lampung province on 11 visits. Areas covered included three subdistricts in Lampung Tengah including Sungkal Selatan, Manggala and Mesuji and Terbanggi Besar for Lampung Tengah.

To understand the extent of the damage of Brontispa longissima Gestro, the damaged leaflets were cut and the population was counted. Thirty (30) coconut palms were selected at random and ten leaflets were taken alternately from each tree, were exatmined for Plesispa reichei Chapuis. The pest that damaged coconut germs, were investigated by using the coconut leaves which were in the seedlings. The presence of Oryctes rhinoceros Linnaeus, Xylotropus gideon (Linnaeus), and Rhynchophorus vulneraturs (Panzer), was determined by examination of the damage caused by the pests or by catching them in the trees.

Observations of coconut pests that damage old leaves and mature leaves from order Lepidoptera, Homoptera and Orthoptera were also carried our by taking samples in the coconut garden. All the leaves from the young non-bearing coconut palms including 2 adult or half adult leaves situated opposite each other were examined to know the species of pests which attacked them were also examined.

The damage to coconut palms by Sus vittatus Temm, were examined by studying their roots. Only the midribs specially the young palms. were observed, for the Rattus spp.

\section{RESULT AND DISCUSSION}

Results of the observation from the 11 visits for the period of 3 years from 1991 until 1993, indicated that in addition to local talls, coconut cultivars: PB- 12 1, PB-111 and Khina-1 and dwarf Salak are also being developed in the areas. The three private landholders showed increased interest to PB- 121 which could be attributed to its increasing production in the area.

The data gathered from the 4 visits (November 1991 - May 1993) to Sungkai Selatan a subdistrict of Lampung Utara as shown in Table 1 indicated that there were 12 species of pests that attacked coconut palms PB 121 and Salak. All the pests attacked the leaves with the exception of 0 . rhinoceros and $R$. vulneratus which attacked the trunk near the sprout (Kalshoven, 1981; Lever, 1969; Tjoa, 1957; 1953). Table 1 also showed that the 12 species of pests which attacked PB-121, H. irava $C$, bandura, E hypermnestra and A. phidippus were not found mi the Salak cultivar. There was a possibility that the pests were not attracted to this kind of palm but it could not be concluded that Salak cultivar was resistant to the pests. To prove further laboratory studies were undertaken by putting the leaves of PB-121 and Salak cultivars in one cage as food for the larvae. From the leaves consumed, the pest preference for coconut cultivars is now established.

Results of the three visits to die Mangala sub-district, Lampung Utara from March 1992 and March 1993 as shown in Table 1 indicated that there were 12 species of pests which attacked the coconut palms in the area. Of the total species, 10 were insects and. 2 others, S Vittatus and Rattus spp. were Mammalian. These data also showed that PB-121 and PB-111 cultivars were attacked by the pests but B. Longissima which did not attack PB-111. This might have been attributed to the beetles being too young or they did not like the cultivars.

According to the result of the one visit to Mesuji, a subdistrict of Larnpung Utara on April 1993, there were a total of 7 species of pests which attacked the 2 cultivars; PB- 121 and PB-111. All of die species with the exception of S. vittatus were categonized as insects. It was however possible 
that there were other species which did not appear at die time of the visit, for either they are being checked by its natural enemy, both predator or parasite, or they could be in imago stadium so that they were not visible in the leaf sample. The species of $R$. vulneratus and $\mathrm{M}$ plana were not found in the leaf of PB-121 while T lutea was not found in Khina-1. Further studies however will be needed to determine the reason for this.

Data gathered during the 3 visits from March 1992 to March 1993 In Terbanggi Besar subdistrict, Lampung Tengah regency, as shown in Table 2 showed the presence of 7 species of pests: including B. longgisima, P. Ledipa, O. rhinoceros, Xyloropus gideon (Linnaeus). A. destructor, Valanga spp., and R. Vulneratus have attacked PB- 121 cultivar (Baringbmig, 1993c; 1992c.).

Table 3 meanwhile showed that there were 19 species of pests in Lampung Utara regency 17 of which fall under the class Insecta and 2 other were Marnmalian. The 17 species of insects belonged to the 4 orders of: Coleopters, Lepidoptera, Homoptera and Orthoptera. Table 3 also showed that in Lampung Tengah regency there were 7 species of pests which all are Insects. It could be concluded that there were 19 species of pests in Lampung Utara and Lampung Selatan regencies; 2 species of them were not insects but Mammalian.

\section{CONCLUSION}

Coconut cultivars: PB-121, PB-111, Khina-1 and dwarf Salak, were developing both in Lampung Utara and Lampung Tengah regencies. Within these two areas, there were 19 species of pests where 17 of them belong to Insecta Class and the other 2 were Marnmalian. 


\section{REFERENCES}

Anonymous, 1990. Coconut Statistical Yearbook 1990. Asian and Pacific Coconut Community. Jakarta 1003, $245 \mathrm{pp}$.

1989. Statistik perkebunan Indonesia tahun 1984 - 1989. Direktorat Jenderal Perkebunan, Jakarta $51 \mathrm{pp}$.

Baringbing, W.A. dan D. Adidharma, 1991. Laporan studi hama penyakit tanaman kelapa dan kakao di kebun Sinar Saerang Mandiri, Sidodadi Lampung Utara. Sub Balai Penelitian Kelapa, Pakuwon. 19 pp.

Baringbing, W.A. dan H. Tampake, 1993. Studi hama kelapa dan kakao di tanah gambut rawa lebak perkebunan PT SAC Nusantara kabupaten Lampung Utara. Sub Balai Penelitian Kelapa, Pakuwon. 21 pp.

Baringbing, W.A. 1993a Studi hama kelapa dan kakao di perkebunan PT Arya Dwipantara kabupaten Lampung Utara. Sub Balai Penelitian Kelapa, Pakuwon. 27 pp.

1993b Hama Oryctes rhinoceros dan Helopeltis antomi di kebun PT Multi Agro Corporation, kabupaten Lampung Tengah. Sub Balai Penelitian Kelapa, Pakuwon. 16 pp

Studi hama kelapa di perkebunan PT Sinar Saerang Mandiri, kabupaten.Lampung Utara. Sub Balai Penelitian Kelapa, Pakuwon (mi press)

1992a Pengamatan hama kelapa di kebun PT Arya Dwipantara, kabupaten Lampung Utara. Sub Balai Penelitian Kelapa, Pakuwon. 17 pp

1992b. Laporan studi hama kelapa di kebun PT Arya Duipantara, kabupaten Lampung Utara. Sub Balal Penelitian Kelapa, Pakawon. 12 pp

1992c Laporan studi hama kelapa di kebun PT Multi Agro Corporation kabupaten Lampung Tengah. Sub Balai Penelitian Kelapa, Pakuwon. 17 pp

1991. Hama kumbang kelapa Oryctes rhinoceros Luimaeus dan cara pengendalianya. Kumpulan makalah seminar tahun 1990/1991. Sub Balai Penelitian Kelapa, Pakuwon. pp. $55-62$.

Kalshoven, L.G.E. 1981. The pests of crops in Indonesia (Rev. ed.) PT Ichtiar Baru - van Hoeve, Jakarta, $701 \mathrm{pp}$.

Lever, R.J.A.W. 1969. Pests of the coconut pahn. FAO, Rome. 190 pp Tjoa, T.M. 1957. Hama-hama tanaman kita. Noordhoff-Kolff NV. Jakarta. 52 pp

1953. Memberantas hama-hama kelapa dan kopra. Noordhoff-Kolff Djakarta. 270 pp. 
Table 1. Pest of hybrids coconut cultivars, PB-121, PB-111, Khina 1, and Dwarf Salak in Lampung Utara regency in 1991-1993

\begin{tabular}{|c|c|c|c|c|c|c|}
\hline Sub- & Time of & Pest species & & CULT & ARS & \\
\hline & & & PB-121 & PB-111 & Khina 1 & Salak \\
\hline $\begin{array}{l}\text { Sungkai } \\
\text { Selatan }\end{array}$ & Nov. 91 & $\begin{array}{l}\text { 1. Hidari irava Moore } \\
\text { 2. Parasa lepida cramer } \\
\text { 3. Setora nitens walker } \\
\text { 4. Brontispa longissima gestro }\end{array}$ & $\begin{array}{l}- \\
- \\
- \\
-\end{array}$ & & & $\begin{array}{l}- \\
- \\
- \\
-\end{array}$ \\
\hline & April 92 & $\begin{array}{l}\text { 1. Setora nitens walker } \\
\text { 2. Brontispa longissima gestro } \\
\text { 3. Oryctes rhinoceros Linnaes } \\
\text { 4. Rhynchophorus vulneratus } \\
\text { (Panzer) }\end{array}$ & $\begin{array}{l}- \\
- \\
- \\
-\end{array}$ & & & $\begin{array}{l}- \\
- \\
- \\
-\end{array}$ \\
\hline & Sept 92 & $\begin{array}{l}\text { 1. Brontispa longissima gestro } \\
\text { 2. Setothosea asigna van Eeke } \\
\text { 3. Thosea lutea Heylaerts }\end{array}$ & $\begin{array}{l}- \\
- \\
-\end{array}$ & & & $\begin{array}{l}- \\
- \\
-\end{array}$ \\
\hline & $\begin{array}{c}\text { Apr-May } \\
1993\end{array}$ & $\begin{array}{l}\text { 1. Sethotosea asigna van Eeke } \\
\text { 2. Parasa lepida cramer } \\
\text { 3. Thosea lutea Heylaerts } \\
\text { 4. Amathusia phidippus Linnaeus } \\
\text { 5. Cania bandura moore } \\
\text { 6. Elymnia hypernestra } \\
\text { (Linnaeus) } \\
\text { 7. Aspidiotus destructor } \\
\text { Signoret } \\
\text { 8. Setora nitens walker } \\
\text { 9. Brontispa longissima Gestro }\end{array}$ & $\begin{array}{l}- \\
- \\
- \\
- \\
- \\
- \\
- \\
- \\
-\end{array}$ & & & $\begin{array}{l}- \\
- \\
- \\
- \\
- \\
- \\
- \\
-\end{array}$ \\
\hline Manggala & Mar 92 & $\begin{array}{l}\text { 1. Valanga spp. } \\
\text { 2. Hidari irava Moore } \\
\text { 3. Mahasena corbeti Tamms } \\
\text { 4. Plesispa reichei chapuis } \\
\text { 5. Brontispa longissima gestro } \\
\text { 6. Aspidiotus destructor signoret } \\
\text { 7. Sus vittatus temm. } \\
\text { 8. Rattus spp. }\end{array}$ & $\begin{array}{l}- \\
- \\
- \\
- \\
- \\
- \\
- \\
-\end{array}$ & & & $\begin{array}{l}- \\
- \\
- \\
- \\
- \\
- \\
- \\
-\end{array}$ \\
\hline & Aug 92 & $\begin{array}{l}\text { 1. Valanga spp } \\
\text { 2. Mahasena corbetti Tamms } \\
\text { 3. Brontispa longissima gestro } \\
\text { 4. Parasa lepida Cramer } \\
\text { 5. Aspidiotus destructor signoret }\end{array}$ & $\begin{array}{l}- \\
- \\
- \\
-\end{array}$ & & & $\begin{array}{l}- \\
- \\
- \\
-\end{array}$ \\
\hline & Mar 93 & $\begin{array}{l}\text { 1. Valanga spp. } \\
\text { 2. Setora nitens walker } \\
\text { 3. Metisa plana walker } \\
\text { 4. Hidari irava Moore } \\
\text { 5. Mahasena corbetti Tamms } \\
\text { 6. Bronstispa longissima gestro } \\
\text { 7. Aspidiotus destructor signoret } \\
\text { 8. Sus vittatus Temm. }\end{array}$ & $\begin{array}{l}- \\
- \\
- \\
- \\
- \\
- \\
- \\
-\end{array}$ & & & $\begin{array}{l}- \\
- \\
- \\
- \\
- \\
- \\
-\end{array}$ \\
\hline Mesuji & Apr 93 & $\begin{array}{l}\text { 1. Oryctes rhinoceros Linnaeus } \\
\text { 2. Rhynchophorus vulneratus } \\
\text { (Panzer) } \\
\text { 3. Valanga spp. } \\
\text { 4. Thosea lutea } \\
\text { 5. Aspidiotus destructor signoret } \\
\text { 6. Metisa plana walker }\end{array}$ & $\begin{array}{l}- \\
- \\
- \\
- \\
- \\
-\end{array}$ & & & $\begin{array}{l}- \\
- \\
- \\
- \\
- \\
-\end{array}$ \\
\hline
\end{tabular}


Table 2. Pests of hybrid coconut cultivars PB-121, PB-111, Khina-1 and Dwarf Salak in Lampung Tengah regency in 1992-1993

\begin{tabular}{|c|c|c|c|c|c|c|}
\hline \multirow{2}{*}{$\begin{array}{l}\text { Sub- } \\
\text { district }\end{array}$} & \multirow{2}{*}{$\begin{array}{c}\text { Time of } \\
\text { Observa } \\
\text { tion }\end{array}$} & \multirow[t]{2}{*}{ Pest species } & \multicolumn{4}{|c|}{ CULTIVARS } \\
\hline & & & PB-121 & PB-111 & Khina 1 & Salak \\
\hline \multirow[t]{3}{*}{$\begin{array}{l}\text { Terbanggi } \\
\text { Besar }\end{array}$} & Mar. 92 & $\begin{array}{l}\text { 1. Bronstispa longissima gestor } \\
\text { 2. Parasa lepida cramer } \\
\text { 3. Oryctes rhinoceros Linnaeus } \\
\text { 4. Xylotropus Gideon Linnaeus } \\
\text { 5. Aspidiotus destructor signoret } \\
\text { 6. Valanga spp. }\end{array}$ & $\begin{array}{l}- \\
- \\
- \\
- \\
-\end{array}$ & & & $\begin{array}{l}- \\
- \\
- \\
- \\
-\end{array}$ \\
\hline & Oct 92 & $\begin{array}{l}\text { 1. Rhynchophorus vulneratus } \\
\text { (Panzer) } \\
\text { 2. Oryctes rhinoceros Linnaes } \\
\text { 3. Brontispa longissima gestro } \\
\text { 4. Aspidiotus destructor signoret } \\
\text { 5. Valanga spp. }\end{array}$ & $\begin{array}{l}- \\
- \\
- \\
- \\
-\end{array}$ & & & $\begin{array}{l}- \\
- \\
- \\
- \\
-\end{array}$ \\
\hline & Mar 93 & $\begin{array}{l}\text { 1. Oryctes rhinoceros Linnaes } \\
\text { 2. Aspidiotus destructor signoret } \\
\text { 3. Parasa lepida cramer } \\
\text { 4. Valanga spp. }\end{array}$ & $\begin{array}{l}- \\
- \\
- \\
-\end{array}$ & & & $\begin{array}{l}- \\
- \\
- \\
-\end{array}$ \\
\hline
\end{tabular}


Table 3. Pests of hybrid coconut cultivars PB-121, PB-111, Khina-1 and Dwarf Salak in Lampung Tengah regency in 1992-1993

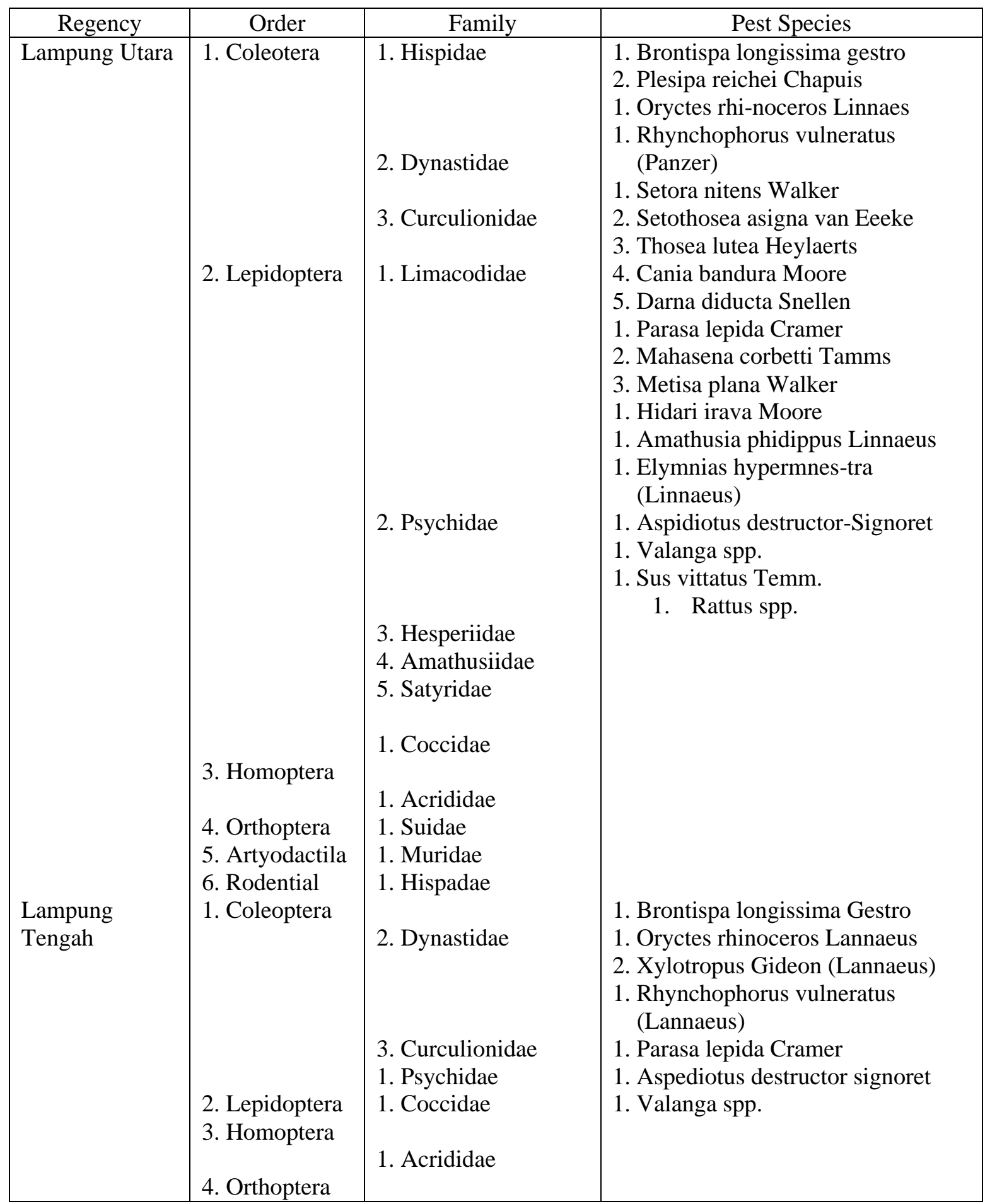

